\title{
H. Carlsson
}

Division of Rock Mechanics

University of Luled

Luleå, Sweden

Reprinted by Lawrence Berkeley Laboratory University of California

Berkeley, Cal ifornia 94720

August, 1978

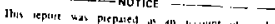

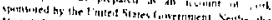

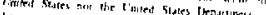

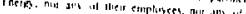

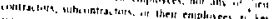

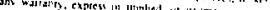

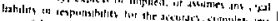

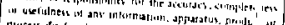

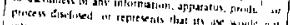

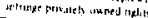

Originally part of KBS Teknisk Rapport 49, Kärnbränslesäkerhet (KBS)

(Swedish Nuclear Fuel Safety Program)

August, 1977 
PREFACE

This report is one of a series documenting the results of the Swedish-American cooperative research program in which the cooperating scientists explore the geological, geophysical, hydrological, geochemical, and structural effects anticipated from the use of a large crystalline rock mass as a geologic repository for nuclear waste. This program has been sponsored by the Swedish Nuclear Power Utilities through the Swedish Nuclear Fuel Supply Company (SKBF), and the U.S. Department of Energy (DOE) through the Lawrence Berkeley Laboratory (LBL).

The principal investigators are L.B. Nilsson and 0 . Degerman for SKBF, and N.G.W. Cook, P.A. Witherspoon, and J.E. Gale for LBL. Other participants will appear as authors of subsequent reports.

Previously published technical reports are listed below.

1. Swedish-American Cooperative Program on Radioactive kaste Storage in Mined Caverns by P.A. Witherspoon and 0. Degerman. (LBL-7049, SAC-01)

2. Large Scale Fermeability Test of the Granite in the Stripa Mine and Thermal conductivitu Test by Lars Lundström and Häken Stille. (LBL-7052, SAC-02)

3. The Mechanical Properties of Stripa Graniti: by Graham Swan (LBL-7074, SAC-03) 
TABLE OF CONTENTS

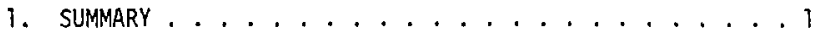

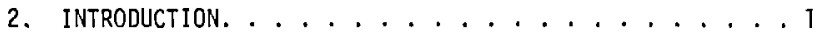

3. SHORT DESCRIPTION OF THE MEASURING METHOD . . . . . 1

4. LOCATION OF BOREHOLE FOR THE MEASUREMENTS . . . . . . 4

5. MECHANICAL PROPERTIES OF THE GRANITE ........ 6

6. RESULTS FROM THE MEASUREMENTS . . . . . . . . . 7

7. COMMENTS ON THE RESULTS ............. 11

8. CORRELATION WITH GEOLOGICAL STRUCTURES . . . . . 12

9. REFERENCES .................. 13 
1. SUMMARY

Rock stress measurements at the $348 \mathrm{~m}$ level of the Stripa Mine have been carried out with the Leeman tri-axial equipment. The largest principal stress is found to be $20.0 \mathrm{MPa}$ and directed parallel with the strike of the contact between the granite and the orebody. The intermediate principal stress is 11.4 $\mathrm{MPa}$ and directed almost horizontal and perpendicular to the contact. The minor principal stress has a magnitude of $5.4 \mathrm{MPa}$. The deduced vertical stress is approximately of the same value as can be theoretically calculated.

\section{INTRODUCTION}

In order to solve the problems of nuclear waste storage the owners of the nuclear plants in Sweden organized Nuclear Fuel Safety (KBS) in late fa11 1976.

Some of the reasearch that KBS performed took place in an abandoned iron ore mine in Stripa, situated in the central part of Sweden. Adjacent to the mine lies a massive body of granite where all experiments have been accomplished.

One of the investigations that took place in the Stripa granite was stress measurements. These have been carried out by the Division of Rock Mechanics, University of Luleå, Sweden.

3. SHORT DESCRIPTION OF THE MEASURING METHOD

The inethod that was used for determination of the stress tensor was the Leeman three-dimensional overcoring method. The method is based upon determination of strain in a borehole by using strain gauges. Twelve strain gauges are divided into three rosettes spaced at an angle of $120^{\circ}$ around the 
perimeter of ar. Ex drill hole. The layout of the rosette is shown in Fig. 1.

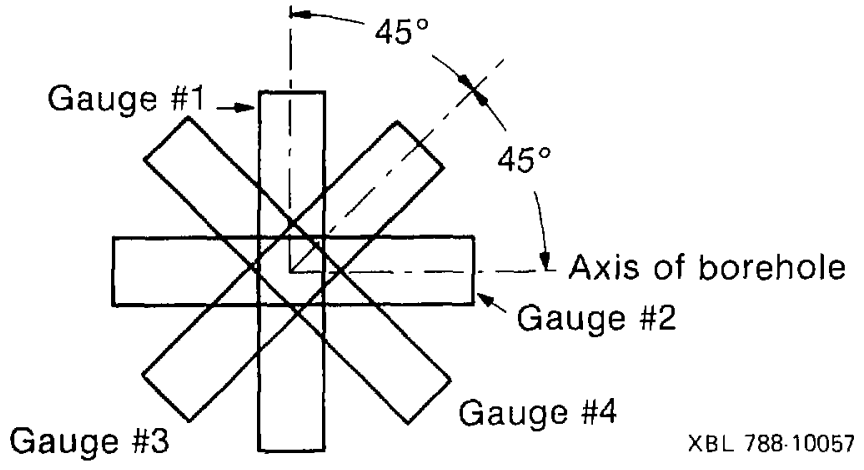

Fig. 1. The strain rosette of a triaxial cel1.

In principle, the way of doing the measurements is shown in Fig. 2. An 86-mm borehole is drilled to the required depth. The botton of the hole is flattened with a full face dianond bit. Concentric with the 86-min borehole an EX hole $(38 \mathrm{~mm})$ is drilled for a distance of $45 \mathrm{~cm}$. After the hole is cleaned, a triaxial strain cell with three strain gauge rosettes is glued in the EX portion of the hole. After the glue has hardened and stable readings of the strain gauges have been recorded, the EX hole is plugged and a cylinder is overcored, as shown in Fig. 2d. The cylinder is then removed from the borehole and the strain obtained is recorded by reading the 12 strain gauges.

In each measuring location the stress tensor can be determined by knowing the Young's Modulus and Poisson's Ratio of the rock. These properties are determined from the core associated with each measuring location in the borehole.

In order to check the reliability of the gauge readings, the overcored cylinder with the bounded triaxial cell is carefully tested in the laboratory. 


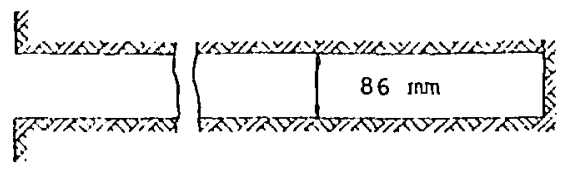
a) The borehole is drilled into the rock mass to the point where the stress in the rock is to be measured.

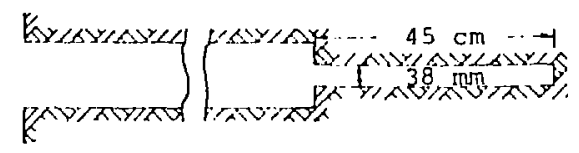
b) A plot hole $45 \mathrm{~cm},: \mathrm{g}$ is drilled into the eno of and concentric with the main borehole.

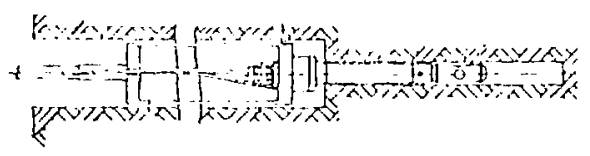
c) After cleaning and drying of the pilot hole, the triaxial cell is inserted and the strain gauges are glued. When the give has set, strain read- ings are taken.

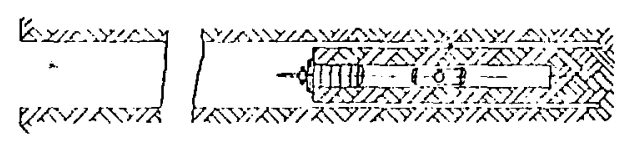
d) The pilot hole is plugged and the triaxial cell is overcored.
e) The core is broken at the end of the borehole and stress re- lieved strain readings are taken.

$X B L 788-10051$

Fig. 2. The principles of rock stress measurements using the overcoring technique. (From Instruction Manual for the use of the C.S.I.R. rock stress measuring equipment.) 


\section{LOCATION OF BOREHOLE FOR THE MEASUREMENTS}

The measurements were carried out in a borehole located in a drift at 348-m leve 1 . Uetermination of direction of the borehole was based upon the strike and dip of visible fractures in the drift. Two dominating sets of fractures were observed. The first set had a strike of $\mathrm{N}-\mathrm{S}$ and a dip of $70^{\circ} \mathrm{W}$. The second set had a strike of $\mathrm{N} 69-70^{\circ} \mathrm{E}$ and a dip of $65^{\circ} \mathrm{W}$. Additional fracture mapping in the main drift of the test site was carried out by SGU (Swedish Geologica? Survey), as shown in Fig. 3.

XBL 788.10056

Fig. 3. Stereographic projection of joint surfaces from the main drift of the test site. Data from olkiewicz, 1977.

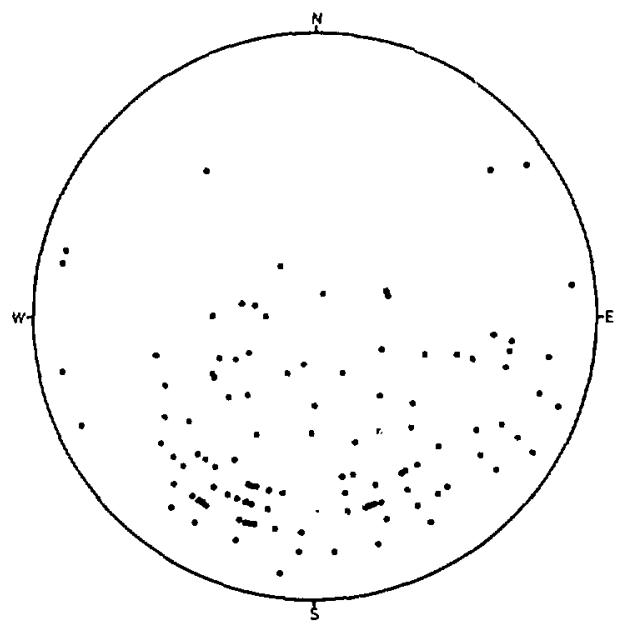

The effort was then made to orient the borehole so that no axial fractures would appear in the core, since this would have affected the continuity of the measurements. A diabase dike in the end of the drift also contributed 
to determining the direction of the borehole. The same dike is observed elsewhere in the mine, and has a width varying between $1.5-2.0 \mathrm{~m}$. The decision was made to drill through the dike and start the measurements at the location in the borehole where the virgin stresses were not affected by the dike. The test site and the direction of the borehole are shown in Fig. 4.

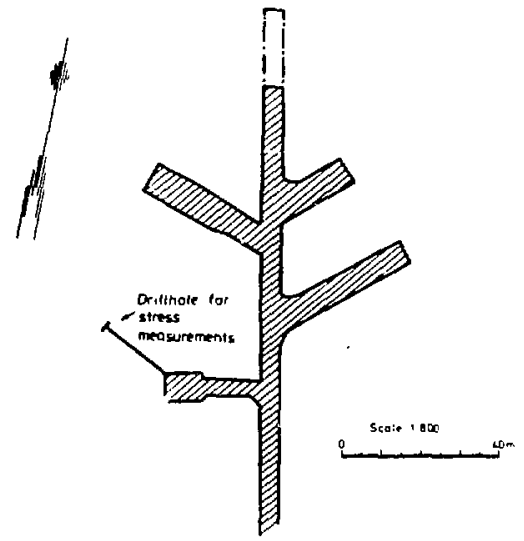

XBL 783-10055

Fig. 4. Location of rock stress measurements at the $348 \mathrm{~m}$ level.

The resuTts from the stress measurements were intended to be used for the purpose of crienting the boreholes in a heater test to be accomplished in the same $\mathrm{dr}^{*} \mathrm{it}$. In order to get a satisfactory and reliable determination of the stress tensor in the granite, the measurements were carried out at a great number of locations in the borehole. 


\section{MECHANICAL PROPERTIES OF THE GRANITE}

For the computation of the stress tensor, Young's Modulus and Poisson's Ratio have to bu known. These parameters have been determined from cores sampled in association with the strain measurement locations in the borehole. The cores have a diameter of $72 \mathrm{~mm}$ and a length of $180 \mathrm{~mm}$, i.e., $1 / \mathrm{d}=2.5$. The determined parameters are tabled below. The values are secantvalues at 50\% failure load.

\begin{tabular}{|c|c|c|c|}
\hline $\begin{array}{c}\text { Depth } \\
{[\mathrm{m}]}\end{array}$ & $\begin{array}{c}\text { Young-s Modulus } \\
{[\mathrm{GPa}]}\end{array}$ & $\begin{array}{c}\text { Poisson's Ratio } \\
v\end{array}$ & $\begin{array}{c}\text { Failure load } \\
{[\mathrm{MPa}]}\end{array}$ \\
\hline 6.03 & 59.97 & 0.19 & 151.39 \\
7.68 & 56.46 & 0.17 & 140.40 \\
8.53 & 59.94 & 0.19 & 152.50 \\
10.10 & 61.68 & 0.22 & 141.40 \\
11.44 & 59.06 & 0.19 & 154.70 \\
$\overline{\mathrm{m}}$ & 59.42 & 0.192 & 148.01 \\
\hline
\end{tabular}

As shown in the table, the variation between Young's Modulus and Poisson's Ratio is very sma11. The decision was made to use $E=59.42 \mathrm{GPa}$ and $v=0.192$ for all computations, since a minar change in these parameters has almost no effect on the magnitudes and no effect on the directions of the stresses. 


\section{RESULTS FROM THE MEASUREMENTS}

The stress tensor has been determined at 19 locations along a 20-m-long subhorizontal borehole at the $348 \mathrm{~m}$ level. As menti.ned earlier, the borehole was drilled through a diabase intercept which ended after $0.87 \mathrm{~m}$. In order to check the influence of the dike on the stresses in the granite, the first measuring location was placed at a depth of $1.55 \mathrm{~m}$ in the borehole. Unfortunately, the diabase again occurs at $2.05 \mathrm{~m}$. At $2.87 \mathrm{~m}$ the diabase ends and the granite persists throughout the remainder of the borehole. Close to the dike the granite was highly fractured, which made it impossible to perform any measurements. As a result of this the second strain measurement was located at $4.41 \mathrm{~m}$. The last strain measurement was located at a depth of $19.63 \mathrm{~m}$.

Table I shows the measured strain for each gauge at eacii location in the borehole. Table II shows the calculated priricipal stresses for each location. In Fig. 5 the principal stresses are platted as a function of depth of the borehole. The orientation of the principal stresses is shown in Fig. 6 . 
Table I. Strain me.2urements from each data point. A Young's Modulus of $59.42 \mathrm{r}_{2} \mathrm{P} i$ and Poisson ${ }^{1}{ }_{5}$ Ratio of 0.732 were used in the calculations.
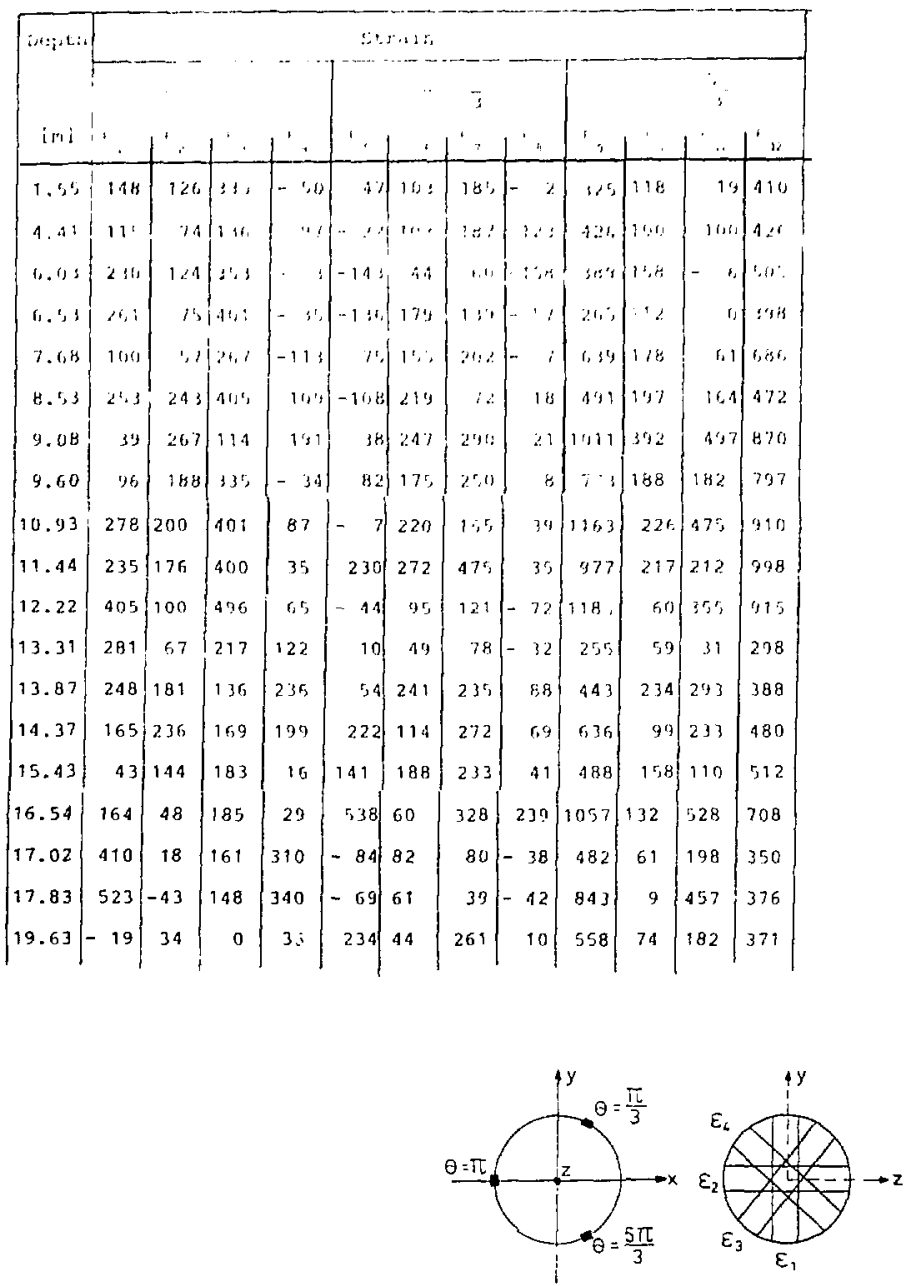
Table II. Calculated principal stresses.

\begin{tabular}{|c|c|c|c|c|c|c|}
\hline \multirow{3}{*}{$\begin{array}{l}\therefore ; \cdots \\
\quad r\end{array}$} & \multirow{2}{*}{\multicolumn{3}{|c|}{ 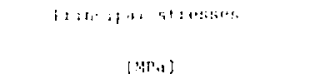 }} & \multirow{3}{*}{$\begin{array}{c}\because: 11: \cdots 1,+\cdots i \\
\vdots: i \cdot 1\end{array}$} & \multirow{2}{*}{\multicolumn{2}{|c|}{ 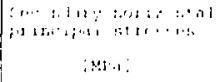 }} \\
\hline & & & & & & \\
\hline & . & $"$ & $\because$ & & is & $n$ \\
\hline 1.5 & 33.41. & $r .08$ & 3.42 & 11.1 .4 & 1.16 & $\ldots \ldots$ \\
\hline 4.41 & 12.28 & 7.48 & $\therefore$. Ar & I. . r: & $\because$ i. & 1.24 \\
\hline c. 1 & $1, \ldots n$ & $r_{1}, r_{1} r$ & 1.511 & $A \cdot \mu$ & 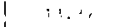 & 1.04 \\
\hline 6.1 & 13.81 & $5.2 b_{3}$ & 1.88 & $1 . .14$ & $M \ldots$ & 4 \& \\
\hline 7.04 & 19.36 & 8. 44 & $4 \cdot 74$ & $11 . r, f_{0}$ & $11, n$ & 4.4 \\
\hline Q.53 & 94.58 & 10.64 & 3.18 & מ. & 1.4 .1 & . . \\
\hline 9.08 & 37.28 & 21.38 & $1.4 \mathrm{P}$ & 17.25 & $\therefore 11$ & $1^{\prime} \ldots$ \\
\hline 3.60 & $2 \pi .0 F_{1}$ & 12.26 & 5.18 & 14.04 & 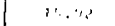 & 11.4 \\
\hline 10.93 & 28.36 & 18.30 & 6.10 & 11).6, 2 & 4.61 & $m, 1 n$ \\
\hline 91.44 & 29.87 & 16.88 & 10.40 & 18.26 & $\therefore 1$, & Ir.ar. \\
\hline 12.22 & 29.52 & 19.74 & f. $8 \mathrm{~d}$ & $10.0,8$ & $\because 1,1$ & $11, \cdots$ \\
\hline 13.31 & 0.78 & C. .44 & 3.28 & 4.82 & 9.87 & 4.80 \\
\hline 13.87 & 16.36 & 12.30 & 5.62 & 14.62 & 14.65 & 5.63 \\
\hline 14.37 & $37.3 r_{1}$ & 13,14 & 7.26 & 10.48 & 15.75 & 11.51 \\
\hline 15.43 & 16.60 & 9.42 & 4.42 & 11.74 & 10.62 & 8.08 \\
\hline 16.54 & 27.5 & 12.68 & 17.30 & 11.56 & 26.70 & 12.21 \\
\hline 17.02 & 14.18 & 9. 70 & 3.30 & 5.98 & 11.85 & 8. 34 \\
\hline 17.83 & 21.58 & 6.48 & 4.08 & 11.62 & 14.68 & 5.86 \\
\hline 19.63 & 13.94 & 6.98 & 2.79 & 3.70 & 13.64 & 6.36 \\
\hline
\end{tabular}




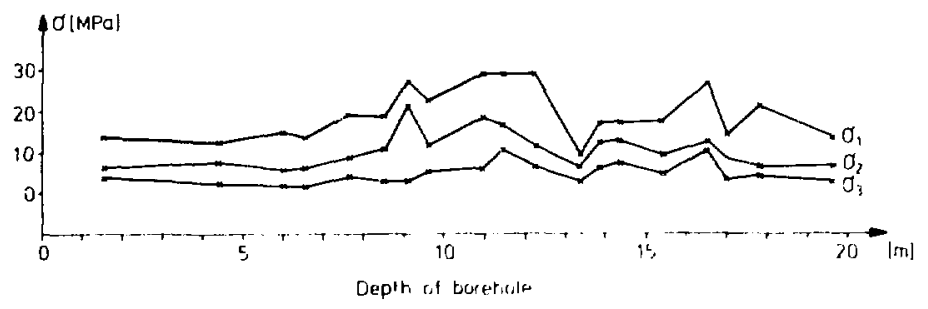

XBL 78810054

Fig. 5. Variation of principal stresses in the borehole.

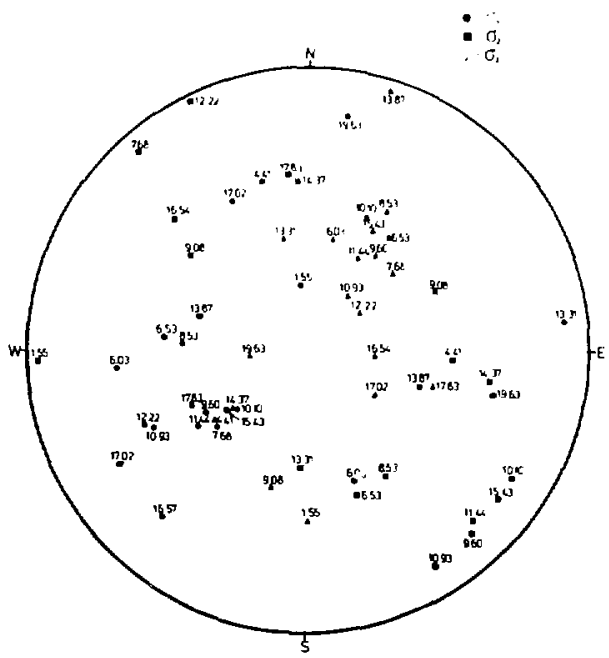

XBL 788-10053

Fig. 6. Direction of principal stresses at each measure point plotted. Depth of measurement in the borehole is indicated on Wullf's net lower hemisphere. 
7. COFMENTS ON THE RESULTS

In spite of the fact that there is a fairly wide scattering of the orientation of the principal stresses, there is a maximum of "1 with a dip of approximately $40^{\circ}$ in the direction of $560^{\circ} \mathrm{W}$. The corresponding maximum for ${ }_{3}$ is a dip of approximately $50^{\circ}$ in the direction of $N 40^{\prime \prime} E$. The medium principal stress is more or less horizontal. The location of these measurements is in the interval 6.03-16.53, i.e., we?l spread along the borehole,

The mean value of the magnitude and orientation of the principal stresses has been calculated within the interval 6.03-16.53 m. The computed principal stresses have been calculated from the mean value of gauges $1,2,3 \ldots 12$ dlong tine borehole. The result, which is plotted in Fig. 7 , shows that the Inaximuln principal stress "1 has the magnitude $20 \mathrm{MPa}$ and is oriented with a dip of $31^{\circ}$ in the direction $568^{\circ} \mathrm{W}$.

XBL 788-10052

Fig. 7. Principal stresses and their directions for the test site, Stripa mine, $348 \mathrm{~m}$ level.

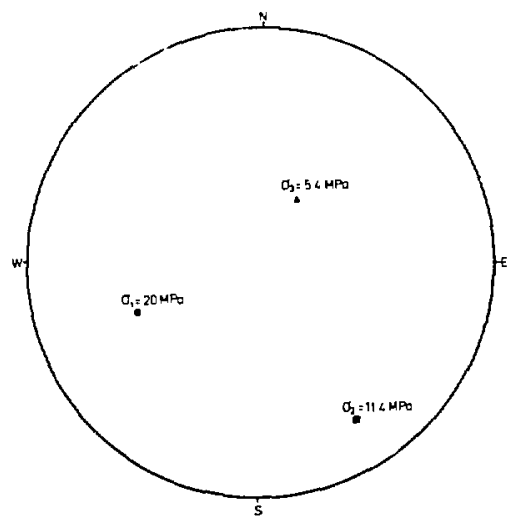




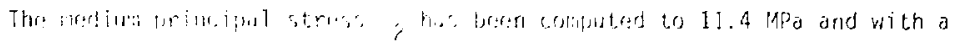
dip of 13' in the firection of ' 3 :

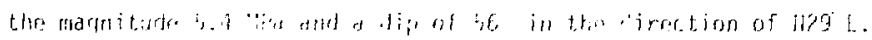

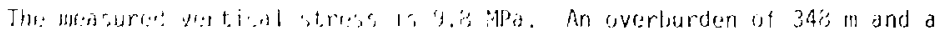

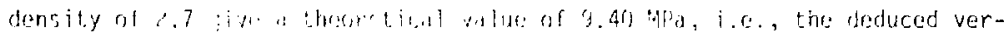

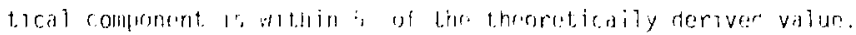

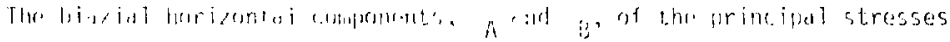

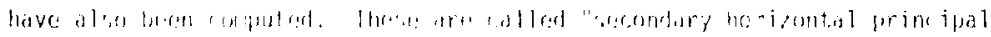

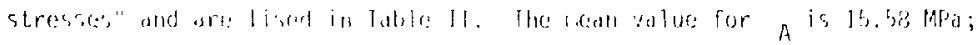

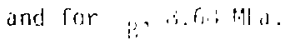

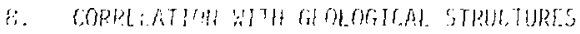

Unfortundti; yory littlo has berm published about the geology and exper ially the tes tomit features of the rocks in the stripd area.

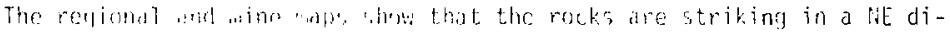
rection ami are stroply dippind trwards SE. Tho ore that was mined at Stripa was a yuartz-bandert iron one. The main ore had the aprearance of a folded

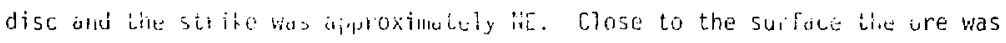
steeply dipping towarts SE, but in deeper regions the dip was very shal low. Bordering the ore was a leptite and a serorogenic granite in which the stress measurements look place. The shallow dip of the ore at deeper regions is believed to be caused 1 the intrusion of the granite.

The contacts botween the rocks undulate both within and between different levels in the mine. At the 348-m level where the meisurements were carried out, a strike of $N 45^{\circ} \mathrm{E}$ can be observed; and the distance to the contact between the granite and the ore is approxinately $100 \mathrm{~m}$. 
The main principal stress 1 is measured to de $20 \mathrm{MPa}$, and the orientation is more or less parallel to the strike of the granite. The medium principal stress, $\because 2$, which has been measured to be $11.4 \mathrm{MPa}$, has a subhorizonta? orientation and the direction is almost perpendicular to the contact of the granite.

It is not certain that the calculated stress tensor is the same for the granite intrusion as a whole. Faults and folds which have a general appearance in the Stripa granite disturo the stress field. The only way to get a more detailed picture of the stress tensor in the stripa granite is to do more measurements at suitable locations in the area.

\section{REFERENICES}

Denkhaus, H. G., Instruction Manual for the Use of the C.S.I.R. Triaxial Rock Stress Measuring Equipment. C.S.I.R. - Report MWF 4401 , Pretoria 1973.

Olkiewicz, A., Personal communication. Swedish Geological Survey, 1977 . 